\title{
Front Matter: Volume 8525
}

, "Front Matter: Volume 8525," Proc. SPIE 8525, Remote Sensing of the Marine Environment II, 852501 (1 July 2013); doi: 10.1117/12.2017664

SPIE. Event: SPIE Asia-Pacific Remote Sensing, 2012, Kyoto, Japan 


\title{
PROCEEDINGS OF SPIE
}

\section{Remote Sensing of the Marine Environment II}

\author{
Robert J. Frouin \\ Naoto Ebuchi \\ Delu Pan \\ Toshiro Saino \\ Editors
}

\section{October - 1 November 2012 \\ Kyoto, Japan}

Sponsored by

SPIE

Cosponsored by

JAXA-Japan Aerospace Exploration Agency (Japan) - NASA-National Aeronautics and Space Administration (United States) - National Institute of Information and Communications Technology (Japan) • Commemorative Organization for the Japan World Exposition (Japan) ISRO_Indian Space Research Organization (India) - State Key Laboratory of Remote Sensing Science (China)

\section{Cooperating Organizations}

ISPRS - International Society for Photogrammetry and Remote Sensing

\section{Supported by}

Japan Society of Atmospheric Environment - Japan Society of Photogrammetry and Remote Sensing • Laser Radar Society of Japan • Meteorological Society of Japan • Optical Society of Japan - Society of Environmental Science, Japan - Society of Geomagnetism and Earth, Planetary and Space Sciences • The Astronomical Society of Japan • The Geodetic Society of Japan - The Institute of Electrical Engineers of Japan - The Institute of Electronics, Information and Communication Engineers - The Japan Society of Applied Physics The Laser Society of Japan • The Remote Sensing Society of Japan • The Society of Instrument and Control Engineers • The Spectroscopical Society of Japan

Published by

SPIE

Volume 8525 
The papers included in this volume were part of the technical conference cited on the cover and title page. Papers were selected and subject to review by the editors and conference program committee. Some conference presentations may not be available for publication. The papers published in these proceedings reflect the work and thoughts of the authors and are published herein as submitted. The publisher is not responsible for the validity of the information or for any outcomes resulting from reliance thereon.

Please use the following format to cite material from this book:

Author(s), "Title of Paper," in Remote Sensing of the Marine Environment II, edited by Robert J. Frouin, Naoto Ebuchi, Delu Pan, Toshiro Saino, Proceedings of SPIE Vol. 8525 (SPIE, Bellingham, WA, 2012) Article CID Number.

ISSN: 0277-786X

ISBN: 9780819492647

Published by

SPIE

P.O. Box 10, Bellingham, Washington 98227-0010 USA

Telephone +1 3606763290 (Pacific Time) · Fax +1 3606471445

SPIE.org

Copyright (C) 2012, Society of Photo-Optical Instrumentation Engineers.

Copying of material in this book for internal or personal use, or for the internal or personal use of specific clients, beyond the fair use provisions granted by the U.S. Copyright Law is authorized by SPIE subject to payment of copying fees. The Transactional Reporting Service base fee for this volume is $\$ 18.00$ per article (or portion thereof), which should be paid directly to the Copyright Clearance Center (CCC), 222 Rosewood Drive, Danvers, MA 01923. Payment may also be made electronically through CCC Online at copyright.com. Other copying for republication, resale, advertising or promotion, or any form of systematic or multiple reproduction of any material in this book is prohibited except with permission in writing from the publisher. The CCC fee code is 0277-786X/12/\$18.00.

Printed in the United States of America.

Publication of record for individual papers is online in the SPIE Digital Library.

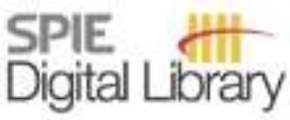

SPIEDigitallibrary.org

Paper Numbering: Proceedings of SPIE follow an e-First publication model, with papers published first online and then in print and on CD-ROM. Papers are published as they are submitted and meet publication criteria. A unique, consistent, permanent citation identifier (CID) number is assigned to each article at the time of the first publication. Utilization of CIDs allows articles to be fully citable as soon as they are published online, and connects the same identifier to all online, print, and electronic versions of the publication. SPIE uses a six-digit CID article numbering system in which:

- The first four digits correspond to the SPIE volume number.

- The last two digits indicate publication order within the volume using a Base 36 numbering

system employing both numerals and letters. These two-number sets start with 00, 01, 02, 03, 04,

$05,06,07,08,09,0 A, 0 B \ldots$. OZ, followed by 10-1Z, 20-2Z, etc.

The CID Number appears on each page of the manuscript. The complete citation is used on the first page, and an abbreviated version on subsequent pages. Numbers in the index correspond to the last two digits of the six-digit CID Number. 


\section{Contents}

vii Conference Committee

ix The benefit of space derived geo-spatial information for sustainable development (Keynote Speech)

Y. Horikawa, Japan Aerospace Exploration Agency (Japan)

xV JAXA Earth Observation Program update (Plenary Paper) [8523-507]

M. Homma, Japan Aerospace Exploration Agency (Japan)

REMOTE SENSING OF SURFACE PROPERTIES

852502 Evaluation of sea surface salinity observed by Aquarius on SAC-D [8525-1]

N. Ebuchi, H. Abe, Hokkaido Univ. (Japan)

852503 Effective monitoring for marine debris after the Great East Japan Earthquake by using spaceborne synthetic aperture radar [8525-2]

M. Arii, Y. Aoki, M. Koiwa, Mitsubishi Space Software Co., Ltd. (Japan)

852504 A new PoISAR ship detector on RADARSAT-2 data [8525-3]

Y. Sun, Graduate Univ. of the Chinese Academy of Sciences (China) and Ctr. for Earth Observation and Digital Earth (China); C. Wang, H. Zhang, F. Wu, B. Zhang, Ctr. for Earth Observation and Digital Earth (China)

852505 Civilian ship classification based on structure features in high resolution SAR images [8525-4]

S. Jiang, Univ. of the Chinese Academy of Sciences (China) and Ctr. for Earth Observation and Digital Earth (China); C. Wang, H. Zhang, F. Wu, B. Zhang, Ctr. for Earth Observation and Digital Earth (China)

852506 A novel normalized scanning algorithm for wake detection in SAR images [8525-5] J. Nan, Univ. of the Chinese Academy of Sciences (China) and Ctr. for Earth Observation and Digital Earth (China); H. Zhang, C. Wang, F. Wu, B. Chen, B. Zhang, Ctr. for Earth Observation and Digital Earth (China)

$8525 \mathrm{OB}$ Seasonal and inter-annual variability of sea surface temperature and sea surface wind in the eastern part of the Indonesian Sea: analysis of ten years of satellite remote sensing data [8525-10]

I. D. N. Nurweda Putra, Yamaguchi Univ. (Japan) and Udayana Univ. (Indonesia);

T. Tanaka, Yamaguchi Univ. (Japan) 
8525 OF Estimation of inherent optical properties using in situ hyperspectral radiometer and MODIS data along the east coast of New Caledonia [8525-14]

H. Murakami, Japan Aerospace Exploration Agency (Japan); C. Dupouy, M.I.O.

AMU/IRD/CNRS/USTV (New Caledonia); R. Röttgers, Helmholtz-Zentrum Geesthacht

(Germany); R. Frouin, Univ. of California, San Diego (United States)

$8525 \mathrm{OH} \quad$ Estimation of total suspended matter from three near infrared bands [8525-17]

M. Toratani, Tokai Univ. (Japan); J. Ishizaka, Nagoya Univ. (Japan); Y. Kiyomoto, Seikai

National Fisheries Research Institute (Japan); Y.-H. Ahn, S. Yoo, Korea Ocean Research and

Development Institute (Korea, Republic of); S.-W. Kim, National Fisheries Research and

Development Institute (Korea, Republic of); J. Tang, National Satellite Ocean Application

Service (China)

\section{OCEAN-COLOR ALGORITHMS AND APPLICATIONS II}

8525 ol Improved ocean-color remote sensing in the Arctic using the POLYMER algorithm [8525-18] R. Frovin, Univ. of California, San Diego (United States); P.-Y. Deschamps, Univ. of California, San Diego (United States) and Hygeos, Euratechnologies (France); D. Ramon, F. Steinmetz, Hygeos, Euratechnologies (France)

8525 OK Spatial and temporal variations of satellite-derived phytoplankton biomass in the Malacca Straits [8525-20]

E. Siswanto, Univ. Teknologi Malaysia (Malaysia); K. Tanaka, Japan International Research Ctr. for Agricultural Sciences (Japan)

$8525 \mathrm{OL}$ Retrieval of chlorophyll-a using satellite and ground spectral data in Japanese and Sri Lankan water bodies [8525-21]

D. D. G. L. Dahanayaka, H. Tonooka, Ibaraki Univ. (Japan); M. J. S. Wijeyaratne, Univ. of Kelaniya (Sri Lanka); A. Minato, S. Ozawa, Ibaraki Univ. (Japan)

8525 OM Remote sensing application for Sardinella lemuru assessment: a case study of the south waters of Malang Regency, East Java, Indonesia [8525-22]

A. B. Sambah, F. Miura, Yamaguchi Univ. (Japan); H. P. Kadarisman, A. Sartimbul, Brawijaya Univ. (Indonesia)

8525 ON Ocean color variability in the southern Atlantic and southeastern Pacific [8525-23] N. M. Rudorff, Instituto Nacional de Pesquisas Espaciais (Brazill); R. J. Frouin, Univ. of California, San Diego (United States); M. Kampel, Instituto Nacional de Pesquisas Espaciais (Brazil)

\section{CORAL REEFS, SEA GRASS, AND MANGROVES I}

852500 Detection of coral bleaching on Sekisei Lagoon using multispectral sensor data [8525-24]

E. Ariyasu, S. Kakuta, Asia Air Survey Co., Ltd. (Japan); N. Asada, Japan Space Systems

(Japan); T. Matsunaga, National Institute for Environmental Studies (Japan) 
$8525 \mathrm{OP}$ Coral reef habitats mapping of Spermonde Archipelago using remote sensing compared with in situ survey of fish abundance [8525-25]

S. Sawayama, The Univ. of Tokyo (Japan); T. Komatsu, Japan Science and Technology

Agency (Japan); N. Nurdin, Hasanuddin Univ. (Indonesia)

$85250 Q \quad$ Mapping seaweed forests with IKONOS image based on bottom surface reflectance [8525-27]

T. Sagawa, Remote Sensing Technology Ctr. of Japan (Japan); A. Mikami, The Univ. of

Tokyo (Japan); M. N. Aoki, Tohoku Univ. (Japan); T. Komatsu, The Univ. of Tokyo (Japan)

CORAL REEFS, SEA GRASS, AND MANGROVES II

8525 OR Comparison of contrast improvement of extracted laver cultivation area using parameters derived from polarimetric SAR data [8525-28]

M. Sugimoto, K. Ouchi, Y. Nakamura, National Defense Academy (Japan)

8525 OS Seagrass mapping using ALOS AVNIR-2 data in Lap An Lagoon, Thua Thien Hue, Viet Nam [8525-29]

H. N. Thang, K. Yoshino, Univ. of Tsukuba (Japan); T. P. Hoang Son, Institute of

Oceanography (Viet Nam)

8525 OT Using remote sensing technique for analyzing temporal changes of seagrass beds by human impacts in waters of Cam Ranh Bay, Vietnam [8525-49]

P. Minh ThU, T. P. Hoang Son, Institute of Oceanography (Viet Nam) and Vietnam Academy of Science and Technology (Viet Nam); T. Komatsu, The Univ. of Tokyo (Japan) and Japan Science and Technology Agency (Japan)

8525 OU Mangrove analysis using ALOS imagery in Hai Phong City, Vietnam [8525-31]

T. D. Pham, Hanoi Univ. of Agriculture (Viet Nam) and Univ. Of Tsukuba (Japan); K. Yoshino, Univ. of Tsukuba (Japan)

8525 OV Marine habitat mapping: using ALOS AVNIR-2 satellite image for seagrass beds at Rabbit (Koh Tonsay) Island, Cambodia [8525-47]

S. Phauk, Royal Univ. of Phnom Penh (Cambodia); T. Komatsu, The Univ. of Tokyo (Japan) and Japan Science and Technology Agency (Japan); S. Sawayama, The Univ. of Tokyo (Japan); T. Noiraksar, Burapha Univ. (Thailand)

8525 oW Evaluation of classification techniques for benthic habitat mapping [8525-32]

A. M. Muslim, Univ. Malaysia Terengganu (Malaysia); T. Komatsu, The Univ. of Tokyo

(Japan); D. Dianacia, Univ. Malaysia Terengganu (Malaysia)

$85250 X$ Did huge tsunami on 11 March 2011 impact seagrass bed distributions in Shizugawa Bay, Sanriku Coast, Japan? [8525-33]

S. Sasa, S. Sawayama, S. Sakamoto, The Univ. of Tokyo (Japan); R. Tsujimoto, G. Terauchi, Northwest Pacific Region Environmental Cooperation Ctr. (Japan); H. Yagi, VisionTech Inc. (Japan); T. Komatsu, The Univ. of Tokyo (Japan)

8525 OY Can ALOS-3/HISUI detect seaweed beds more precisely than ALOS/AVNIR-2? [8525-34] T. Sagawa, T. Watanabe, Remote Sensing Technology Ctr. of Japan (Japan); A. Watanuki, T. Koike, Alpha Hydraulic Engineering Consultants Co., Ltd. (Japan); H. Kamimura, Japan Aerospace Exploration Agency (Japan); T. Komatsu, The Univ. of Tokyo (Japan) 
852510 A preliminary study on the application of remotely sensed SST in locating evaporation duct height [8525-36]

M. H. A. Baig, Nanjing Univ. of Information Science and Technology (China) and Institute of Remote Sensing Applications (China); Z. Wang, Nanjing Univ. of Information Science and Technology (China); L. Zhang, Institute of Remote Sensing Applications (China); L. Yang, Nanjing Univ. of Information Science and Technology (China)

852512 Status and threats on seagrass beds using GIS in Vietnam [8525-38]

C. V. Luong, N. V. Thao, Institute of Marine Environment and Resources (Viet Nam); T. Komatsu, Univ. of Tokyo (Japan) and Japan Science and Technology Agency (Japan): N. D. Ve, D. D. Tien, Institute of Marine Environment and Resources (Viet Nam)

852513 Monitoring of debris flowing in the ocean generated by huge tsunami caused by the 2011 earthquake off the Pacific coast of Tohoku [8525-39]

T. Aoyama, Fukui Univ. of Technology (Japan)

852519 A time series of photosynthetically available radiation at the ocean surface from SeaWiFS and MODIS data [8525-45]

R. Frouin, J. McPherson, K. Ueyoshi, Univ. of California, San Diego (United States);

B. A. Franz, NASA Goddard Space Flight Ctr. (United States)

85251 A Spectral response of the coral rubble, living corals, and dead corals: study case on the Spermonde archipelago, Indonesia [8525-46]

N. Nurdin, Hasanuddin Univ. (Indonesia); T. Komatsu, The Univ. of Tokyo (Japan) and Japan Science and Technology Agency (Japan); H. Yamano, National Institute for Environmental Studies (Japan); G. Arafat, C. Rani, Hasanuddin Univ. (Indonesia); M. Akbar AS, SEAMEO Biotrop (Indonesia)

8525 1B Impact of huge tsunami in March 2011 on seaweed bed distributions in Shizugawa Bay, Sanriku Coast, revealed by remote sensing [8525-48]

S. X. Sakamoto, S. Sasa, S. Sawayama, The Univ. of Tokyo (Japan); R. Tsujimoto, G. Terauchi, Northwest Pacific Region Environmental Cooperation Ctr. (Japan); H. Yagi, VisionTech Inc. (Japan); T. Komatsu, The Univ. of Tokyo (Japan) and Japan Science and Technology Agency (Japan)

Author Index 


\title{
Conference Committee
}

\author{
Symposium Chairs \\ Upendra N. Singh, NASA Langley Research Center (United States) \\ Toshio Iguchi, National Institute of Information and Communications \\ Technology (Japan) \\ Symposium Cochair
}

A. S. Kiran Kumar, Space Applications Centre (India)

Conference Chairs

Robert J. Frouin, Scripps Institution of Oceanography (United States)

Naoto Ebuchi, Hokkaido University (Japan)

Delu Pan, The Second Institute of Oceanography, SOA (China)

Toshiro Saino, Japan Agency for Marine-Earth Science and

Technology (Japan)

Conference Program Committee

David P. Doxaran, Laboratoire d'Océanographie de Villefranche (France)

Cécile Dupouy, Institut de Recherche pour le Développement (New Caledonia)

Joji Ishizaka, Nagoya University (Japan)

Zhongping Lee, Boston University (United States)

Hubert Loisel, Université du Littoral Côte d'Opale (France)

Mervyn J. Lynch, Curtin University of Technology (Australia)

Hiroshi Murakami, Japan Aerospace Exploration Agency (Japan)

Kevin Ruddick, Royal Belgian Institute of Natural Sciences (Belgium)

Menghua Wang, NOAA/NESDIS Center for Satellite Applications and Research (United States)

Sinjae Yoo, Korea Ocean Research and Development Institute

(Korea, Republic of)

Session Chairs

1 Remote Sensing of Surface Properties I

Naoto Ebuchi, Hokkaido University (Japan)

2 Remote Sensing of Surface Properties II

Naoto Ebuchi, Hokkaido University (Japan) 
3 Ocean-Color Algorithms and Applications I

Toshiro Saino, Japan Agency for Marine-Earth Science and Technology (Japan)

4 Ocean-Color Algorithms and Applications II

Toshiro Saino, Japan Agency for Marine-Earth Science and Technology (Japan)

5 Coral Reefs, Sea Grass, and Mangroves I

Robert J. Frouin, Scripps Institution of Oceanography (United States)

6 Coral Reefs, Sea Grass, and Mangroves II

Robert J. Frouin, Scripps Institution of Oceanography (United States) 